\title{
REHABILITASI EKOSISTEM PADANG LAMUN
}

R O C H M A D Y

P 3300209019 


\section{PENDAHULUAN}

Ekosistem pesisir dan laut merupakan ekosistem alamiah yang produktif, unik dan mempunyai nilai ekologis dan ekonomis yang tinggi. Selain menghasilkan bahan dasar untuk pemenuhan kebutuhan pangan, keperluan rumah tangga dan industri yang dalam konteks ekonomi bernilai komersial tinggi, ekosistem pesisir dan laut juga memiliki fungsi-fungsi ekologis penting, antara lain sebagai penyedia nutrien, sebagai tempat pemijahan, tempat pengasuhan dan tumbuh besar, serta tempat mencari makanan bagi beragam biota laut. Di samping itu, ekosistem pesisir dan laut berperan pula sebagai pelindung pantai atau penahan abrasi bagi wilayah daratan yang berada di belakang ekosistem ini (Bengen, 2002).

Wilayah pesisir merupakan pusat interaksi antara darat dengan laut. Wilayah ini berperan sebagai penyangga, pelindung dan penyaring di antara daratan dan lautan, serta merupakan pemusatan terbesar penduduk. Komponen hayati dan nirhayati secara fungsional berhubungan satu sama lain dan saling berinteraksi membentuk suatu sistem, yang dikenal dengan ekosistem. Apabila terjadi perubahan pada salah satu dari kedua komponen tersebut, maka akan dapat mempengaruhi keseluruhan sistem yang ada, baik dalam kesatuan struktur fungsional maupun dalam keseimbangannya.

Wilayah pesisir merupakan wilayah yang penting, ditinjau dari berbagai sudut pandang perencanaan dan pengelolaan, salah satunya adalah ekosistem padang lamun, di samping ekosistem lainnya. Transisi antara daratan dan lautan di wilayah pesisir telah membentuk ekosistem yang beragam dan sangat produktif serta memberikan nilai ekonomi yang luar biasa terhadap manusia. Wilayah ini juga sebagai sumber kehidupan bagi beraneka ragam biota. Keough \& Jenkin (.....), padang lamun yang dijumpai di alam sering berasosiasi dengan flora dan fauna akuatik lainnya, seperti alga, meiofauna, moluska, ekinodermata, krustasea dan berbagai jenis ikan. 


\section{EKOSISTEM PADANG LAMUN}

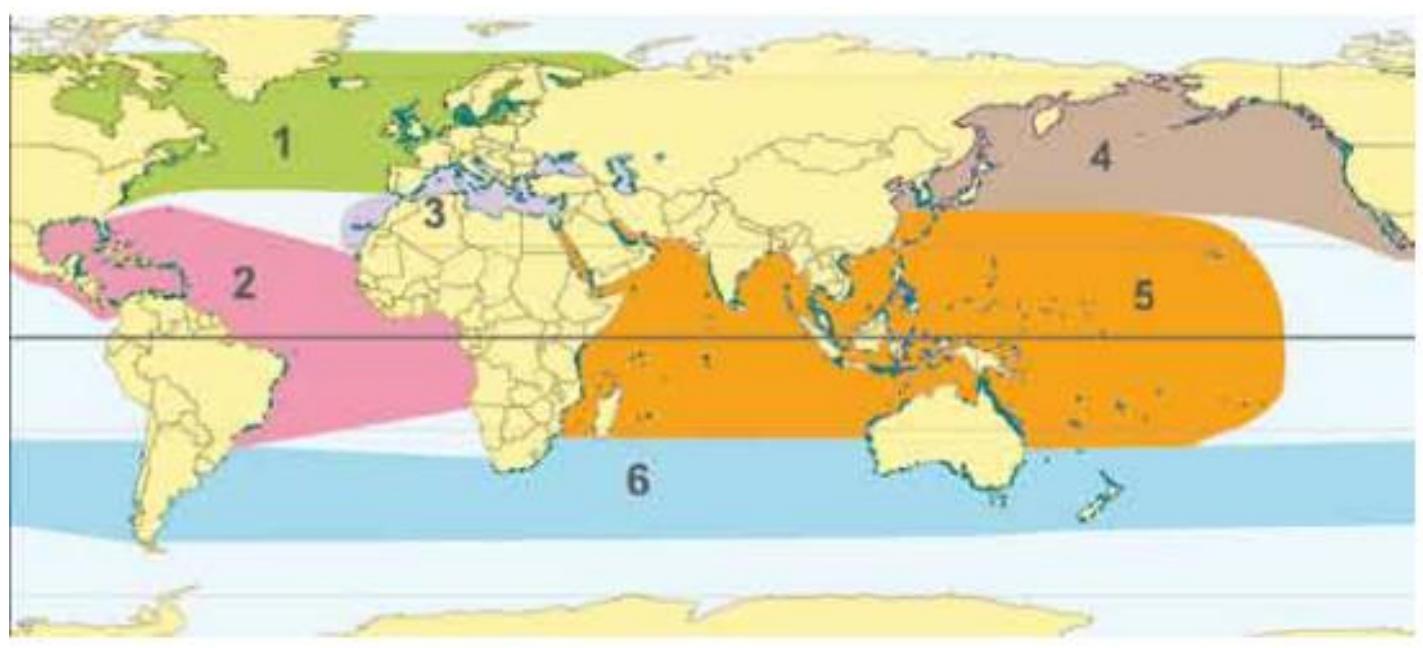

Global seagrass distribution shown as blue points and polygons and geographic bioregions: 1. Temperate North Atlantic, 2. Tropical Atlantic, 3. Mediterranean, 4. Temperate North Pacific, 5. Tropical Indo-Pacific, 6. Temperate Southern Oceans from Short et al. 2007.

Ogden \& Gladfelter dalam Bengen (2002), ekosistem padang lamun bukan merupakan entitas yang terisolasi, tetapi berinteraksi dengan ekosistem lain di sekitarnya. Interaksi terpenting ekosistem padang lamun adalah dengan ekosistem mangrove dan terumbu karang, dimana terdapat 5 tipe interaksi antara ketiga ekosistem tersebut: fisik, bahan organik terlarut, bahan organik partikel, migrasi fauna dan dampak manusia.

Padang lamun merupakan ekosistem yang tinggi produktivitas organiknya, sehingga tumbuhan lamun dan beraneka ragam serta berlimpahnya organisme yang berasosiasi dengan padang lamun dapat dimanfaatkan sebagai: tempat pemancingan, wisata bahari, bahan baku pakan artifisial untuk ikan dan hewan ternak, sumber pupuk hijau, areal marikultur (ikan, teripang, kerang, tiram, dan rumput laut), bahan baku kerajinan anyaman, dan sebagainya. 


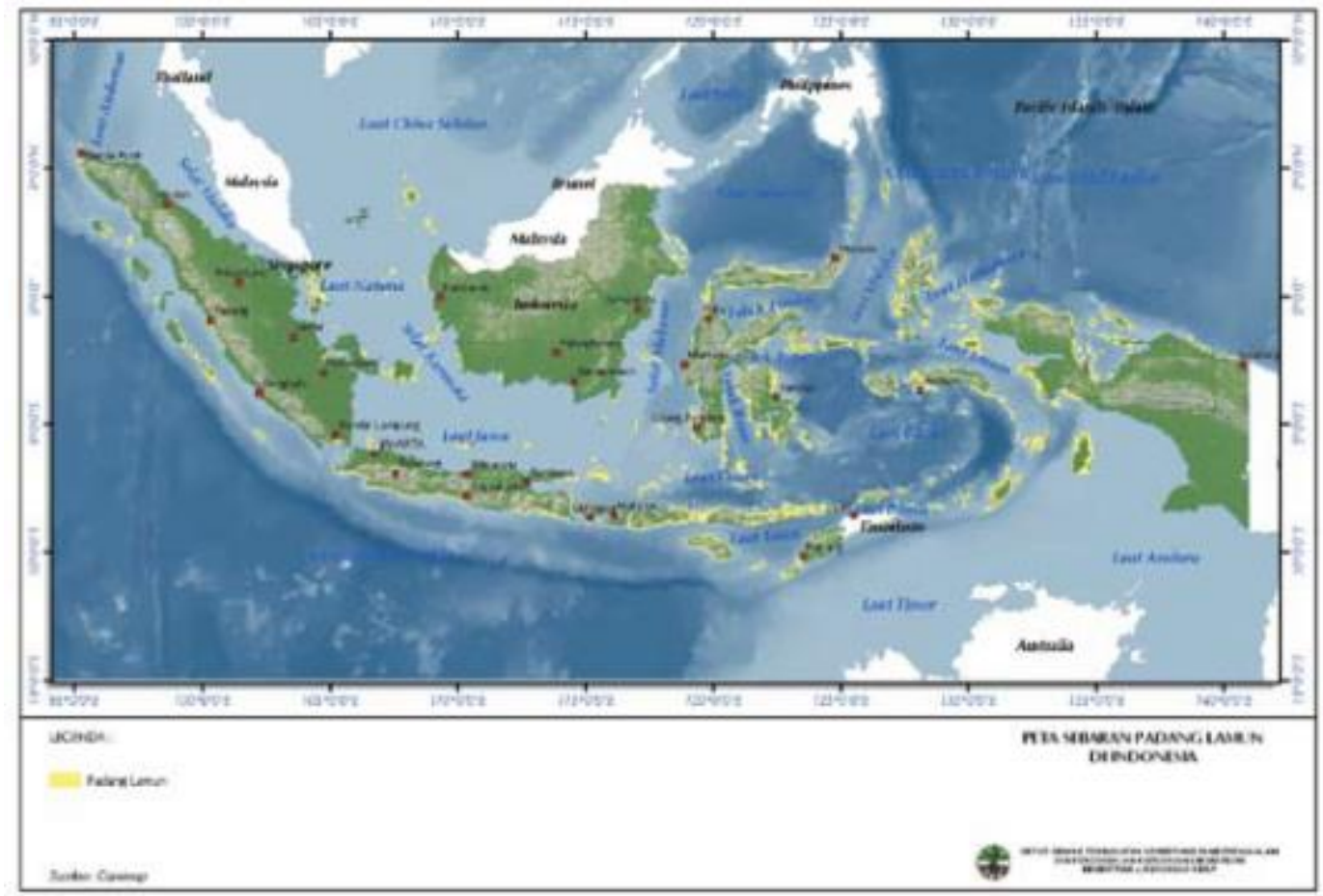

Sumber: KLH, 2008 (Dipetakan kembali dari Peta Sebaran Terumbu Karang Coremap 2006)

Peta ekosistem Padang Lamun di Indonesia

Pemanfaatan potensi dari nilai padang lamun dapat meningkatkan kesejahteraan masyarakat, tetapi tanpa pengelolaan yang berkelanjutan maka akan mengurangi fungsi dari ekosistem ini. Kegiatan manusia dalam memanfaatkan sumberdaya padang lamun, sering kali menimbulkan dampak negatif terhadap kelestariannya. Padang lamun di Indonesia telah banyak mengalami kemunduran kualitas, baik akibat proses-proses alami maupun akibat aktivitas manusia. Aktivitas manusia yang banyak mengancam padang lamun adalah dampak aktivitas penangkapan ikan, buangan limbah dan sampah, pencemaran, aktivitas rekreasi, aktivitas pelayaran dan tempat berlabuh, buangan sisa-sisa industri dan pabrik, dan lain-lain.

Dalam menghadapi kompetisi yang serius untuk mendapatkan ruang di pesisir, proses pembangunan harus mencari suatu keseimbangan dari kegiatan yang ada tanpa mengabaikan produktivitas yang berasal dari sumber daya utama. Pengelolaan dan perencanaan zona pesisir terpadu dipilih sebagai suatu metoda 
pemanfaatan dan konservasi sumber daya untuk menjawab masalah-masalah spesifik seperti kerusakan yang terjadi pada sumber daya dan konflik antar pengguna daerah pesisir. Identifikasi terhadap masalah-masalah wilayah pesisir yang berhubungan dengan kepentingan masyarakat juga memberikan perangsang kepada badan-badan dan masyarakat yang mempunyai kepentingan untuk melestarikan sumber daya dan pendapatan mereka, melibatkan, berperan dan melaksanakan program-program guna memberikan jalan keluar terhadap kesulitan yang telah diidentifikasikan.

Padang lamun di Indonesia yang diperkirakan seluas sekitar $30.000 \mathrm{~km}^{2}$ mempunyai peran penting sebagai habitat ikan dan berbagai biota lainnya. Berbagai jenis ikan yang bernilai ekonomi penting menjadikan padang lamun sebagai tempat mencari makan, berlindung, bertelur, memijah dan sebagai daerah asuhan. Padang lamun juga berperan penting untuk menjaga kestabilan garis pantai.

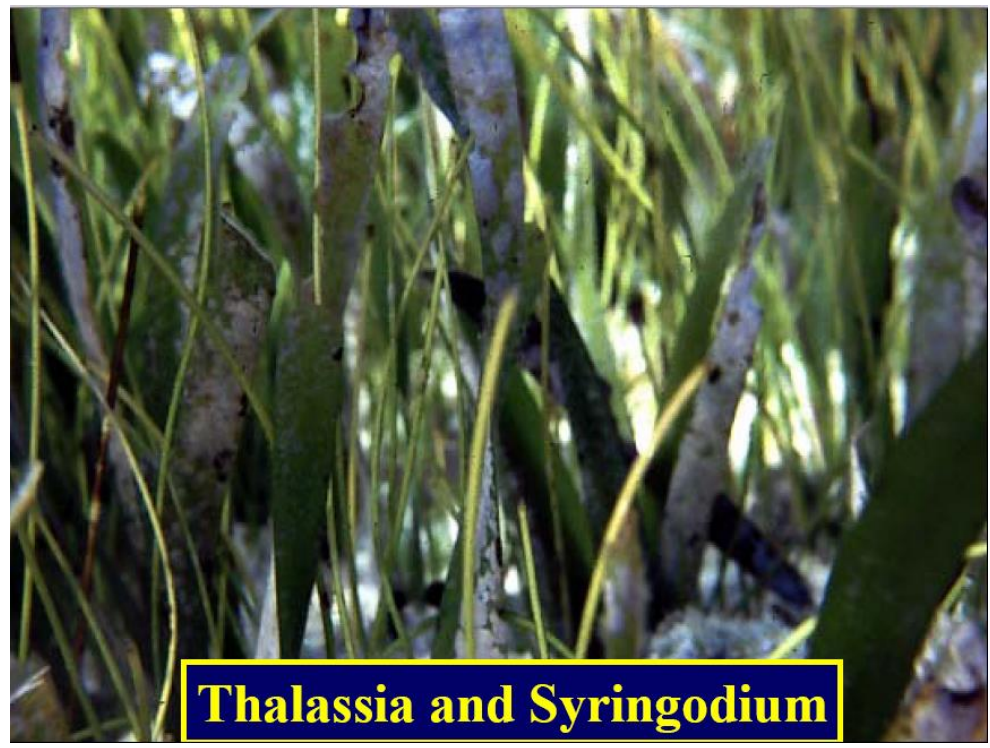

\section{Lamun (Seagrass)}

Lamun memiliki perbedaan yang nyata dengan tumbuhan yang hidup terbenam dalam laut lainnya, seperti makro alga atau rumput laut (seaweeds). Tanaman lamun memiliki bunga dan buah yang kemudian berkembang menjadi 
benih. Pertumbuhan lamun sangat dipengaruhi oleh faktor-faktor internal seperti kondisi fisiologis dan metabolisme; serta faktor eksternal, seperti zat-zat hara dan tingkat kesuburan perairan.

Dahuri (2003), lamun tumbuh subur terutama di daerah terbuka pasang surut dan perairan pantai atau goba yang dasarnya berupa lumpur, pasir, kerikil, dan patahan karang mati, dengan kedalaman 4 meter. Padang lamun terbentuk di dasar laut yang masih ditembusi cahaya matahari yang cukup untuk pertumbuhannya.

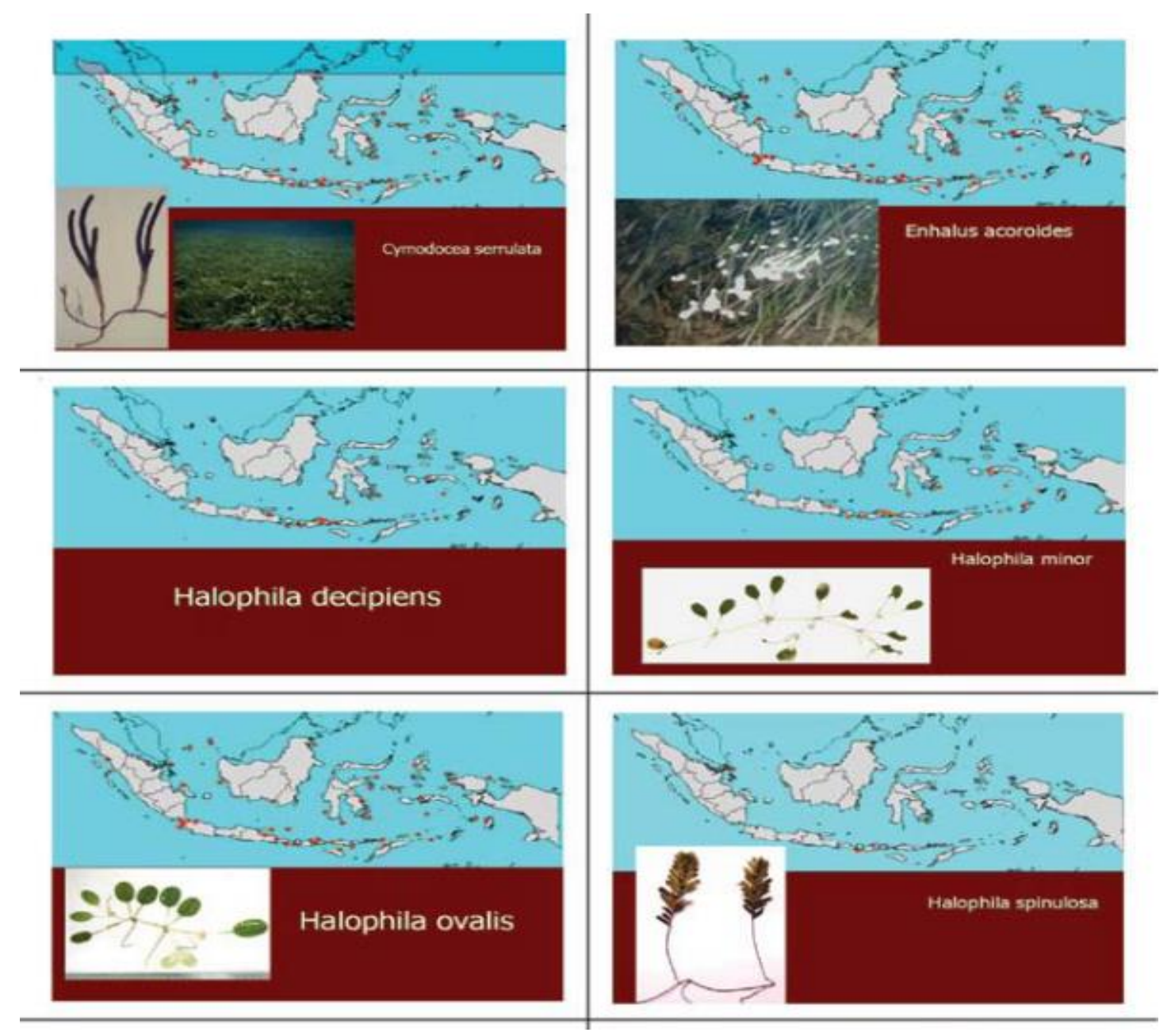




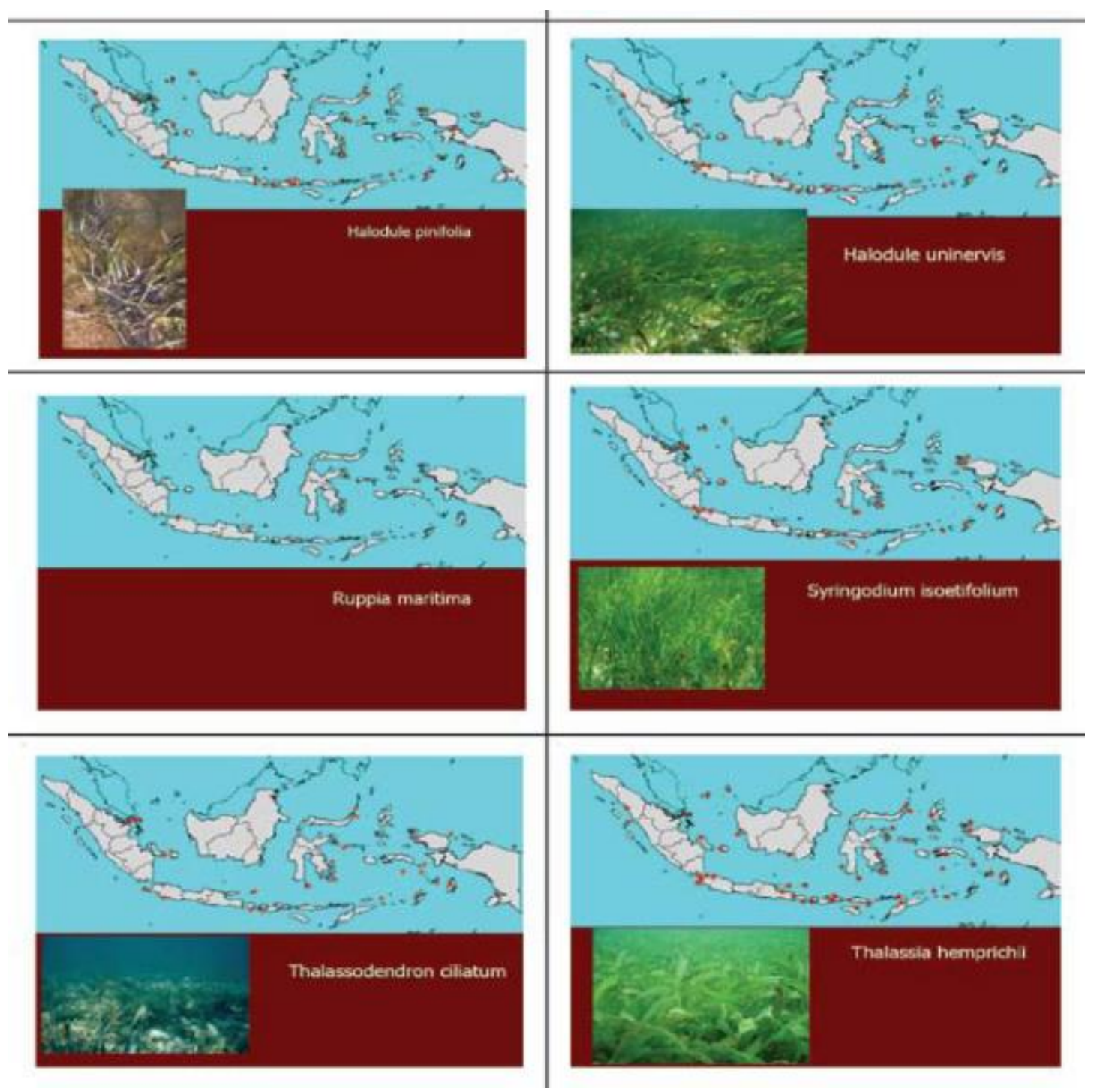

Peta sebaran Padang Lamun di Indonesia.

Di seluruh dunia diperkirakan terdapat sebanyak 55 jenis lamun, dimana di Indonesia ditemukan sekitar 12 jenis dominan. Hampir semua substrat dapat ditumbuhi lamun, mulai dari substrat berlumpur sampai berbatu. Namun padang lamun yang luas lebih sering ditemukan disubstrat lumpur-berpasir yang tebal antara hutan rawa mangrove dan terumbu karang (Bengen, 2002). Beberapa spesies seperti Thalassia testudinum secara ekstrim dapat bertumbuh dengan cepat, dengan laju pertumbuhan daun $2 \mathrm{~cm}$ per hari. Pertambahan panjang rhizoma, sesuai jenisnya, ada yang mencapai 100-200 cm per tahun (Keough \& Jenkin, ....). 
Ekosistem padang lamun berfungsi sebagai penyuplai energi, baik pada zona bentik maupun pelagis. Detritus daun lamun yang tua didekomposisi oleh sekumpulan jasad bentik (seperti teripang, kerang, kepiting, dan bakteri), sehingga dihasilkan bahan organik, baik yang tersuspensi maupun yang terlarut dalam bentuk nutrien. Nutrien tersebut tidak hanya bermanfaat bagi tumbuhan lamun, tetapi juga bermanfaat untuk pertumbuhan fitoplankton dan selanjutnya zooplankton, dan juvenil ikan/udang (Dahuri, 2003).

\section{Fungsi dan Peranan}

Padang lamun merupakan ekosistem yang tinggi produktifitas organiknya, dengan keanekaragaman biota yang cukup tinggi. Pada ekosistem ini hidup beraneka ragam biota laut seperti ikan, Krustasea, Moluska ( Pinna sp., Lambis sp., dan Strombus sp.), Ekinodermata (Holothuria sp., Synapta sp., Diadema sp., Arcbaster sp., Linckia sp.) dan cacing ( Polichaeta) (Bengen, 2001).

Menurut Azkab (1988), ekosistem lamun merupakan salah satu ekosistem di laut dangkal yang paling produktif. Di samping itu ekosistem lamun mempunyai peranan penting dalam menunjang kehidupan dan perkembangan jasad hidup di laut dangkal, menurut hasil penelitian diketahui bahwa peranan lamun di

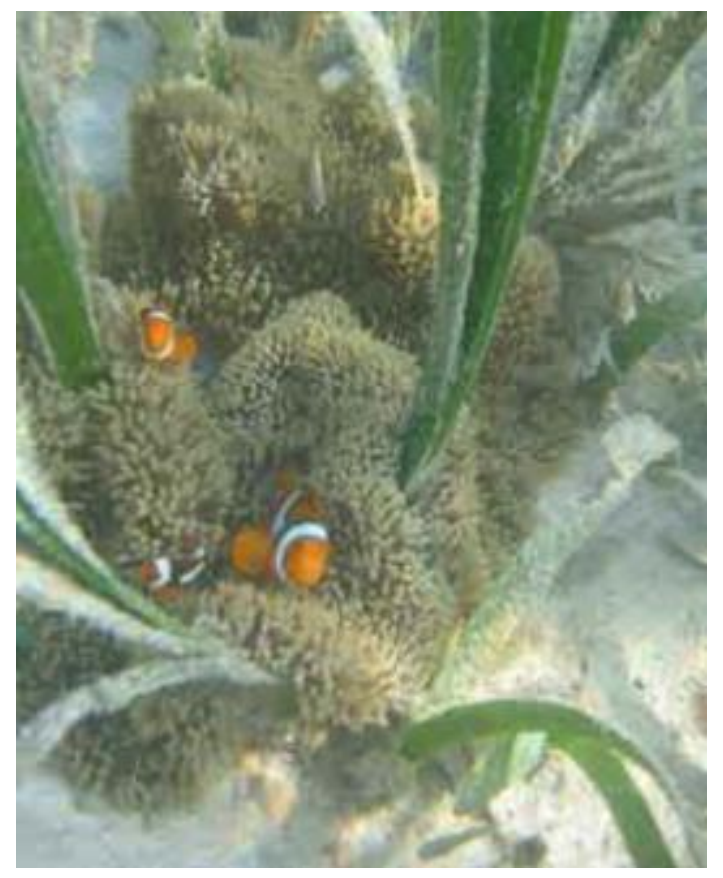
lingkungan perairan laut dangkal sebagai berikut:

1. Sebagai produsen primer

Lamun mempunyai tingkat produktifitas primer tertinggi bila dibandingkan dengan ekosistem lainnya yang ada di laut dangkal seperti ekosistem terumbu karang (Thayer et al. 1975).

2. Sebagai habitat biota 
Lamun memberikan tempat perlindungan dan tempat menempel berbagai hewan dan tumbuh-tumbuhan (alga). Disamping itu, padang lamun (seagrass beds) dapat juga sebagai daerah asuhan, padang pengembalaan dan makan dari berbagai jenis ikan herbivora dan ikan- ikan karang (coral fishes) (Kikuchi \& Peres, 1977).

\section{Sebagai penangkap sedimen}

Daun lamun yang lebat akan memperlambat air yang disebabkan oleh arus dan ombak, sehingga perairan di sekitarnya menjadi tenang. Disamping itu, rimpang dan akar lamun dapat menahan dan mengikat sedimen, sehingga dapat menguatkan dan menstabilkan dasar permukaaan. Jadi padang lamun yang berfungsi sebagai penangkap sedimen dapat mencegah erosi ( Gingsburg \& Lowestan 1958).

4. Sebagai pendaur zat hara

Lamun memegang peranan penting dalam pendauran barbagai zat hara dan elemen-elemen yang langka di lingkungan laut. Khususnya zat-zat hara yang dibutuhkan oleh algae epifit.

Sedangkan menurut Philips \& Menez (1988), ekosistem lamun merupakan salah satu ekosistem bahari yang produktif. ekosistem lamun perairan dangkal mempunyai fungsi antara lain:

1. Menstabilkan dan menahan sedimen-sedimen yang dibawa melalui I tekanantekanan dari arus dan gelombang.

2. Daun-daun memperlambat dan mengurangi arus dan gelombang serta mengembangkan sedimentasi.

3. Memberikan perlindungan terhadap hewan-hewan muda dan dewasa yang berkunjung ke padang lamun.

4. Daun-daun sangat membantu organisme-organisme epifit.

5. Mempunyai produktifitas dan pertumbuhan yang tinggi. 
6. Menfiksasi karbon yang sebagian besar masuk ke dalam sistem daur rantai makanan.

Selanjutnya dikatakan Philips \& Menez (1988), lamun juga sebagai komoditi yang sudah banyak dimanfaatkan oleh masyarakat baik secara tradisional maupuin secara modern. Secara tradisional lamun telah dimanfaatkan untuk :

1. Digunakan untuk kompos dan pupuk

2. Cerutu dan mainan anak-anak

3. Dianyam menjadi keranjang

4. Tumpukan untuk pematang

5. Mengisi kasur

6. Ada yang dimakan

7. Dibuat jaring ikan

Pada zaman modern ini, lamun telah dimanfaatkan untuk:

1. Penyaring limbah

2. Stabilizator pantai

3. Bahan untuk pabrik kertas

4. Makanan

5. Obat-obatan

6. Sumber bahan kimia.

Lamun kadang-kadang membentuk suatu komunitas yang merupakan habitat bagi berbagai jenis hewan laut. Komunitas lamun ini juga dapat memperlambat gerakan air. bahkan ada jenis lamun yang dapat dikonsumsi bagi penduduk sekitar pantai. Keberadaan ekosistem padang lamun masih belum banyak dikenal baik pada kalangan akdemisi maupun masyarakat umum, jika dibandingkan dengan ekosistem lain seperti ekosistem terumnbu karang dan ekosistem mangrove, meskipun diantara ekosistem tersebut di kawasan pesisir merupakan satu kesatuan sistem dalam menjalankan fungsi ekologisnya. 
Lamun hidup dan terdapat pada daerah mid-intertidal sampai kedalaman 0,5-10 m. Namun sangat melimpah di daerah sublitoral. Jumlah spesies lebih banyak terdapat di daerah tropik dari pada di daerah ugahari (Barber, 1985).

Habitat lamun dapat dipandang sebagai suatu komunitas, dalam hal ini suatu padang lamun merupakan kerangka struktur dengan tumbuhan dan hewan yang saling berhubungan. Habitat lamun dapat juga dipandang sabagai suatu ekosistem, dalam hal ini hubungan hewan dan tumbuhan tadi dipandang sebagai suatu proses tunggal yang dikendalikan oleh pengaruh-pengaruh interaktif dari faktor-faktor biologis, fisika, kimiawi. Ekosistem padang lamun pada daerah tropik dapat menempati berbagai habitat, dalam hal ini status nutrien yang diperlukan sangat berpengaruh. Lamun dapat hidup mulai dari rendah nutrien dan melimpah pada habitat yang tinggi nutrien.

Lamun pada umumnya dianggap sebagai kelompok tumbuhan yang homogen. Lamun terlihat mempunyai kaitan dengan habitat dimana banyak lamun (Thalassia) adalah substrat dasar dengan pasir kasar. Menurut Haruna (Sangaji, 1994) juga mendapatkan Enhalus acoroides dominan hidup pada substrat dasar berpasir dan pasir sedikit berlumpur dan kadang-kadang terdapat pada dasar yang terdiri atas campuran pecahan karang yang telah mati. 


\section{ANCAMAN EKOSISTEM PADANG LAMUN}

Suatu ekosistem pesisir terjadi pertukaran materi dan transformasi energi yang berlangsung di antara kedua komponen dalam sistem tersebut, maupun dengan komponen-komponen dari sistem lain di luarnya. Kelangsungan suatu fungsi ekosistem sangat menentukan kelestarian dari sumberdaya alam sebagai komponen yang terlibat dalam sistem tersebut. Karena itu untuk menjamin kelestarian sumberdaya alam, perlu diperhatikan hubungan-hubungan ekologi yang berlangsung di antara komponen-komponen sumberdaya alam yang menyusun suatu sistem (Bengen, 2002).

Walaupun potensi sumberdaya hayati pesisir dan

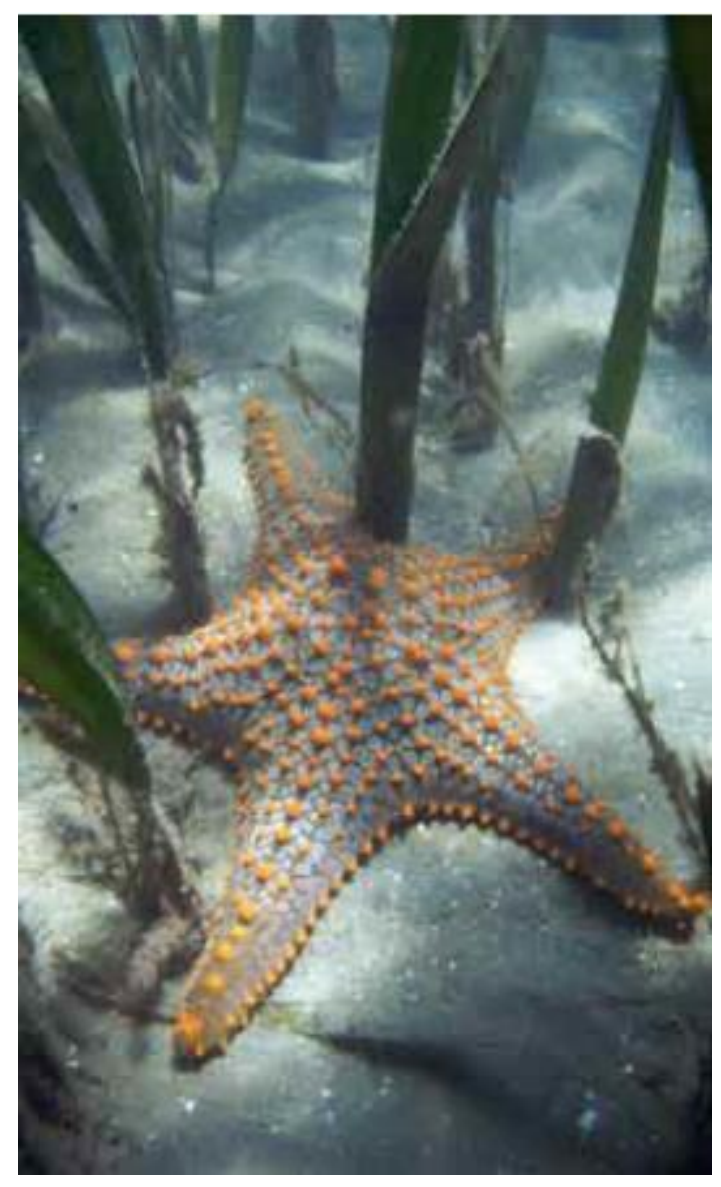
laut sangat kaya namun sebagian besar masyarakat yang bermukim di pesisir masih berada dibawah garis kemiskinan. Hal ini menjadi salah satu faktor pendorong masyarakat pesisir untuk mengeksploitasi sumberdaya kelautan melebihi daya dukungnya agar mereka dapat memenuhi kebutuhan hidupnya.

Bengen \& Rizal (2002), kemiskinan merupakan salah satu penyebab kerusakan sumberdaya hayati, namun sebaliknya kemiskinan juga merupakan akibat yang timbul dari kerusakan yang dialami oleh sumberdaya hayati. Untuk itu pemanfaatan sumberdaya harus tepat secara ekologi, teknologi dan ekonomi agar di suatu kawasan tidak terjadi over eksploitasi padahal di kawasan yang lain belum dimanfaatkan optimal.

Ekosistem padang lamun mempunya potensi ekonomi yang sangat besar. Potensi ini mendorong pengambilan sumberdaya yang dikandungnya secara berlebihan dan tanpa mengindahkan kaidah-kaidah konservasi. Karena adanya asumsi bahwa sumberdaya yang berada di ekosistem padang lamun adalah milik bersama (common property), sehingga bila tidak dimanfaatkan pada saat ini maka akan dimanfaatkan orang lain (tragedy of common). Untuk mengeksploitasi 
sumberdaya hayati tersebut digunakan cara-cara destruktif, mis. untuk menangkap ikan digunakan racun sianida, bahan peledak, dan lain-lain yang semuanya itu dapat merusak ekosistem padang lamun.

Ancaman yang mengakibatkan terdegrasinya ekosistem padang lamun bisa disebabkan dari aktivitas manusia (pertanian, pertambakan, industri, pertambangan, pengembangan kota, reklamasi, dsb.) dan pengaruh dari proses-proses alami (angin, arus, hujan, gelombang, dsb.). Pemanfaatan padang lamun seperti yang dikemukakan pada bab sebelumnya (sebagai areal marikultur, tempat pariwisata, rekreasi, bahan baku pakan, dan pupuk hijau) jika tanpa pengelolaan yang terpadu dan berkelanjutan dapat berakibat negatif pada ekosistem tersebut.

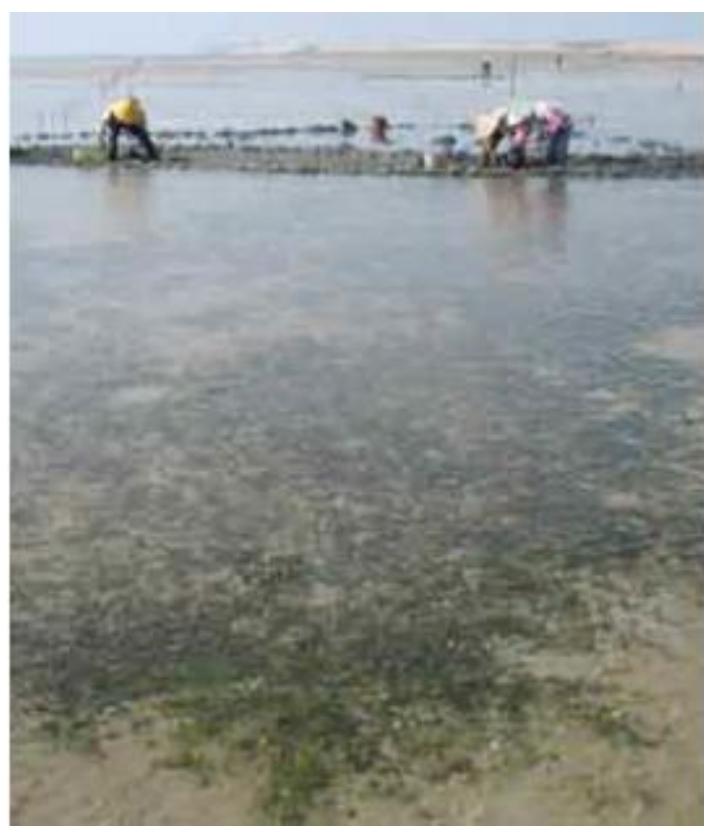

Singkatnya dampak kegiatan manusia terhadap padang lamun dapat dilihat pada tabel 2 berikut :

Tabel 2. Dampak kegiatan terhadap padang lamun

\begin{tabular}{|c|l|l|}
\hline No & \multicolumn{1}{|c|}{ Kegiatan } & \multicolumn{1}{c|}{ Dampak } \\
\hline 1 & $\begin{array}{l}\text { Pengerukan dan pengurugan } \\
\text { untuk kegiatan di pinggir laut, } \\
\text { pelabuhan, industrial estate, } \\
\text { saluran navigasi }\end{array}$ & $\begin{array}{l}\text { Perusakan total padang lamun sebagai lokasi } \\
\text { pengerukan dan pengurugan } \\
\text { Perusakan habitat di lokasi pembuangan hasil } \\
\text { pengerukan } \\
\text { Dampak sekunder pada perairan meningkatkan } \\
\text { kekeruhan air dan terlapisnya insang hewan air. }\end{array}$ \\
\hline 2 & Pencemaran limbah industri & $\begin{array}{l}\text { Lamun melalui proses biological magnification } \\
\text { mampu mengakumulasi logam berat. }\end{array}$ \\
\hline 3 & Pembuangan sampah organik & $\begin{array}{l}\text { Penurunan kadar oksigen terlarut, mengganggu } \\
\text { lamun dan hewan air. } \\
\text { Eutrofikasi menyebabkan blooming } \\
\text { fitoplankton yang menempel di daun lamun dan } \\
\text { kekeruhan menghalangi cahaya. }\end{array}$ \\
\hline 4 & $\begin{array}{l}\text { Pencemaran oleh limbah } \\
\text { pertanian }\end{array}$ & $\begin{array}{l}\text { Pestisida, mematikan hewan yang berasosiasi } \\
\text { dengan padang lamun, pupuk mengakibatkan } \\
\text { eutrofikasi }\end{array}$ \\
\hline 5 & Pencemaran minyak & $\begin{array}{l}\text { Lapisan minyak pada daun lamun menghalangi } \\
\text { lamun untuk berfotositesis }\end{array}$ \\
\hline
\end{tabular}

Sumber : Bengen (2003) 
Sebagaimana ekosistem pesisir lainnya, padang lamun memiliki faktorfaktor pembatas yang mempengaruhi distribusi serta tumbuh dan berkembangnya. Bengen (2003), faktor-faktor pembatas ekosistem padang lamun adalah: karbon (CO2 dan HCO3-), cahaya, temperatur, salinitas, pergerakan air, dan nutrien. Dahuri (2003), kisaran temperatur optimal bagi spesies lamun $28-30{ }^{\circ} \mathrm{C}$, salinitas $10-40 \%$ optimal $35 \%$, \& kecepatan arus $0.5 \mathrm{~m} /$ detik.

Aktivitas manusia yang berlebihan di lahan atas dapat meningkatkan muatan sedimen pada badan air akan berakibat pada tingginya kekeruhan perairan, sehingga berpotensi mengurangi penetrasi cahaya. Hal ini dapat menimbulkan gangguan terhadap produktivitas primer ekosistem padang lamun karena lamun membutuhkan intensitas cahaya yang tinggi untuk berfotosintesis.

Pemanasan global dan limbah industri pabrik akan meningkatkan suhu perairan. Lamun mempunyai toleransi yang rendah terhadap perubahan temperatur. Kemampuan proses fotosintesis akan menurun dengan tajam apabila temperatur perairan berada di luar kisaran optimal. Spesies lamun memiliki kemampuan toleransi yang berbeda-beda terhadap salinitas. Salah satu faktor yang menyebabkan kerusakan ekosistem padang lamun adalah meningkatknya salinitas yang diakibatkan oleh berkurangnya suplai air tawar dari sungai.

Interaksi ekosistem padang lamun dengan ekosistem hutan mangrove sangat menentukan tipe substrat. Pengrusakan ekosistem hutan mangrove dapat menghilangkan salah satu fungsinya sebagai perangkap sedimen. Tanpa hutan mangrove maka sedimen dari darat akan hanyut dan menyebar ke laut. Padahal dengan terperangkapnya sedimen di hutan mangrove secara perlahan dan dalam jumlah yang besar akan bergeser ke padang lamun. Dahuri (2003), kedalaman substrat berperan dalam menjaga stabilitas sedimen yang mencakup dua hal, yaitu pelindung lamun dari arus air laut, dan tempat pengolahan serta pemasok nutrien. Kedalaman sedimen yang cukup merupakan kebutuhan utama untuk pertumbuhan dan perkembangan habitat lamun. 
Tetapi juga sedimen yang mengandung bahan pencemar dan terperangkap di ekosistem pesisir merupakan masalah serius degradasi likungan. Bengen (2002), pembukaan lahan atas sebagai bagian dari kegiatan pertanian, telah meningkatkan limbah pertanian, baik padat maupun cair yang masuk perairan pesisir dan laut melalui aliran sungai. Limbah cair yang mengandung nitrogen dan fosfor berpotensi menimbulkan keadaan lewat subur (eutrofikasi) yang merugikan ekosistem pesisir.

Dalam perkembangannya banyak daerah lamun yang telah mengalami gangguan atau kerusakan karena gangguan alam ataupun karena aktivitas manusia. Gangguan atau tekanan oleh aktivitas manusia yang berlangsung terus menerus menimbulkan dampak yang lebih besar. Akar masalah perusakan padang lamun antara lain karena ketidak-tahuan masyarakat, kemiskinan, keserakahan, lemahnya perundangan dan penegakan hukum. Oleh karena itu pengelolaan padang lamun harus mengatasi masalah mendasar itu dalam upaya rehabilitasi padang lamun. Rehabilitasi padang lamun dapat di lakukan dengan dua pendekatan yakni: rehabilitasi lunak dan rehabilitasi keras. Rehabilitasi lunak lebih ditekankan pada pengendalian perilaku manusia yang menjadi penyebab kerusakan lingkungan, misalnya melalui kampanye penyadaran masyarakat (public awareness), pendidikan, pengembangan mata pencaharian alternatif, pengembangan Daerah Perlindungan Padang Lamun, pengembangan peraturan dan perundangan, dan penegakan hukum secara konsisten. Rehabilitasi keras mencakup kegiatan rehabilitasi langsung di lapangan seperti transplantasi lamun.

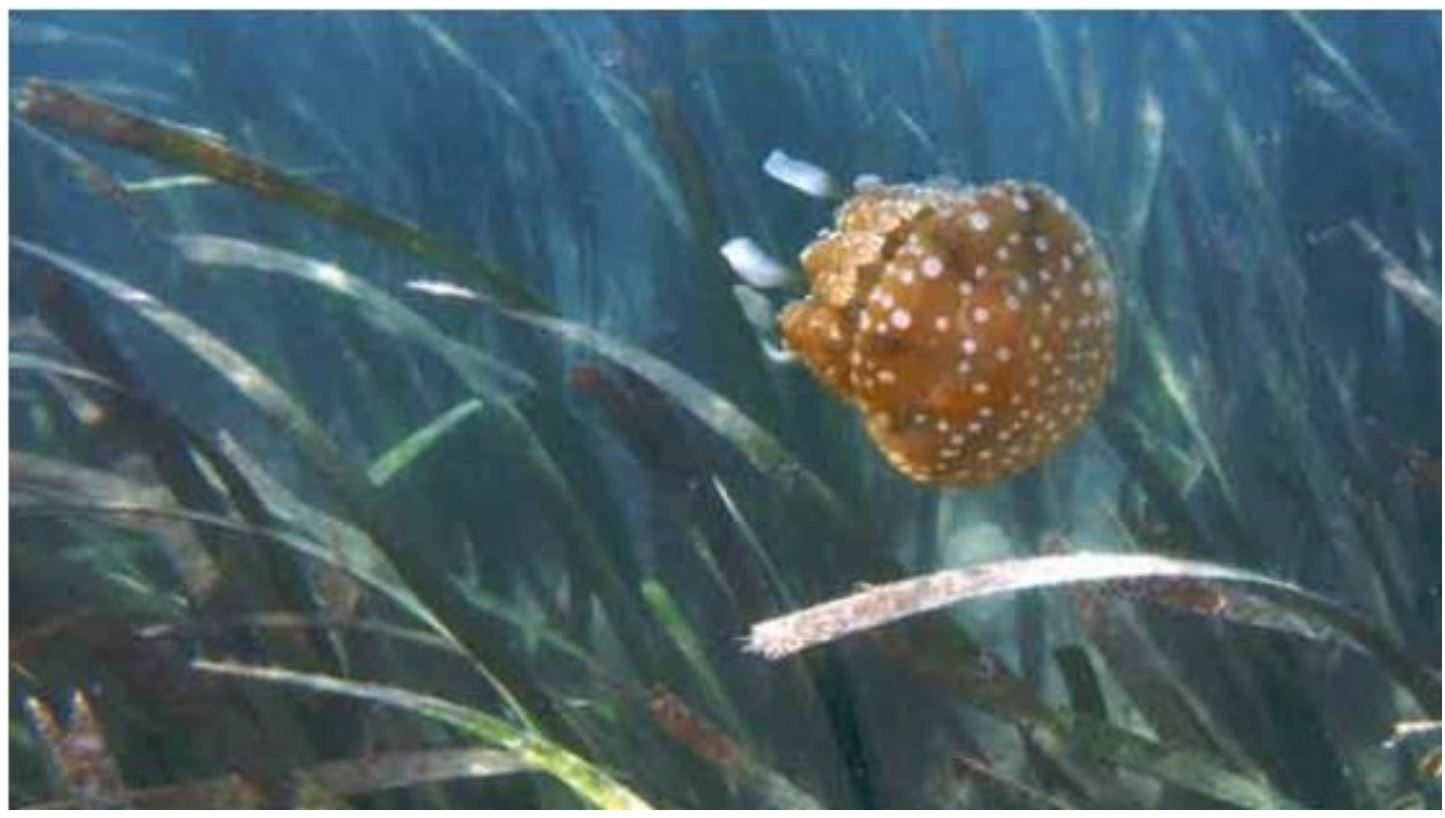




\section{UPAYA RESTORASI DAN REHABILITASI}

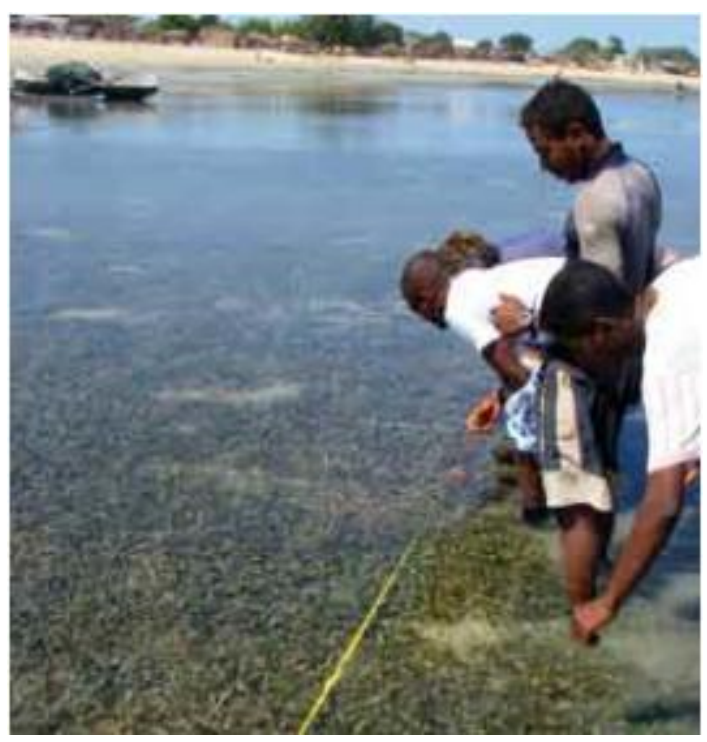

Karena padang lamun mungkin akan rusak akibat berbagai aktivitas manusia sebagai dampak dari kegiatan pembangunan pada daerah pantai, maka metode penanaman atau transplantasi lamun dikembangkan sebagai salah satu cara untuk memperbaiki atau mengembalikan habitat yang mengalami kerusakan. Cara ini telah banyak dilakukan oleh para ahli di luar negeri dengan metode dan jenis yang berbeda. Pertama dimulai oleh Addy tahun 1947 pada jenis Zostera marina, Thallasia testudinum dan Holodule wrightii dan jenis Thallasia testudinum.

\section{Metode Penanaman}

Metode penanaman atau transplantasi yang pernah dilakukan oleh Addy, Burkho Dohemy, Kelly, Thorhaug dan Phillips adalah :

\section{Metode pembibitan/pembenihan (Seed/Seeding)}

Biji biasanya dikoleksi dari buah yang tua atau diambil dari bibit yang tumbuh pada permukaan sedimen. Untuk memanennya, buah dipotong dari tangkainya dan dipecah, maka kelihatan 4 atau 5 biji dan benih segera ditanam dan disirami air laut yang mengalir. Menurut Thorhaug (1974), bahwa sampai saat ini pengetahuan teknik untk pembenihan masih sangat sedikit, sehingga penanaman dengan biji tidak direkomendasikan untuk penanaman lamun. Hal ini juga berkaitan dengan biji yang kurang sukses untuk jenis lamun ini. Disamping itu, secara umum, biji

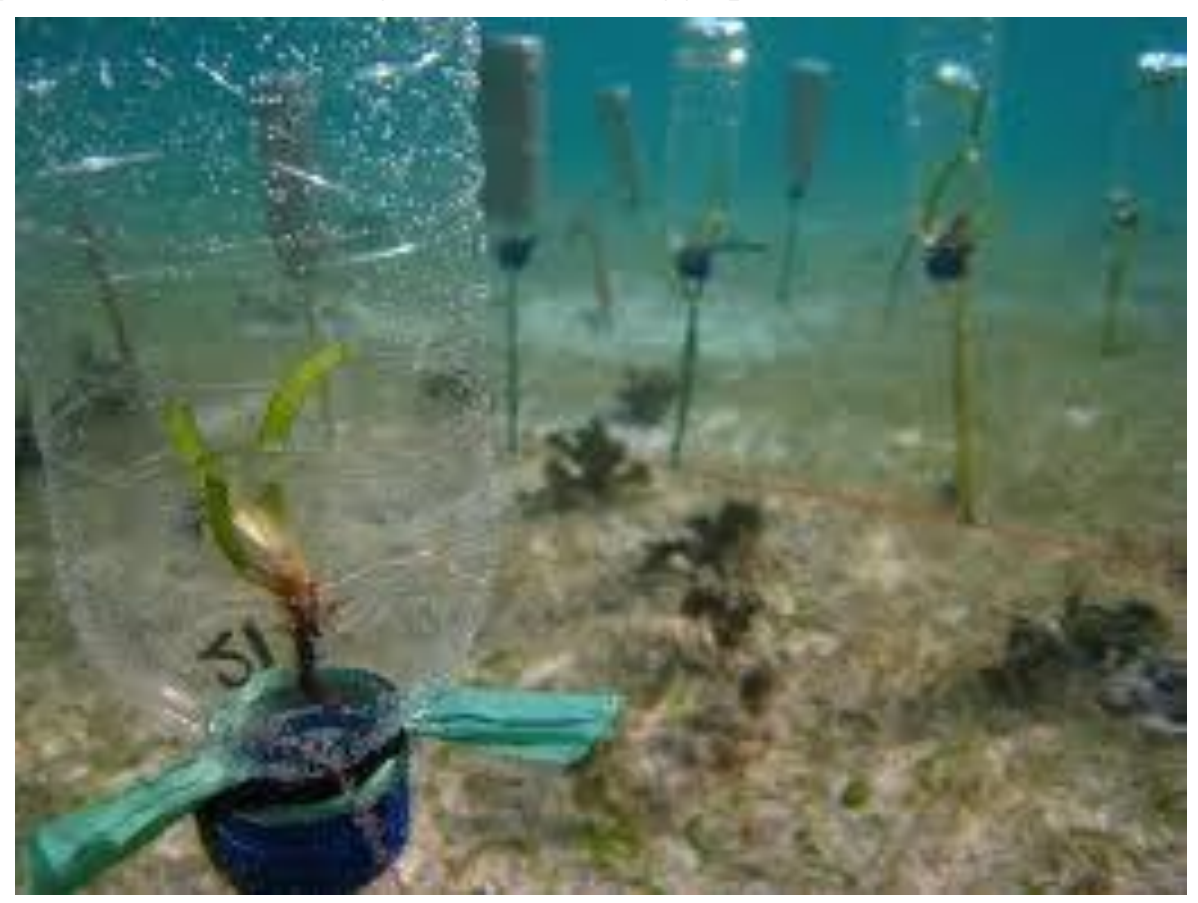


atau benih lamun sangat kecil dan mudah terbawa air serta kecepatan perkecambahan sangat rendah.

\section{Metode Sprig dengan jangkar atau tanpa jangkar}

Yaitu pengambilan bibit tanaman dengan pisau/parang dan ditransplantasi tanpa substratnya. Untuk penanaman dengan metode spring dengan jangkar biasanya dilakukan pada arus dengan 1,5 knot (kira-kira 3 $\mathrm{km}$ per jam) atau pada daerah dengan gelombang akibat angin.

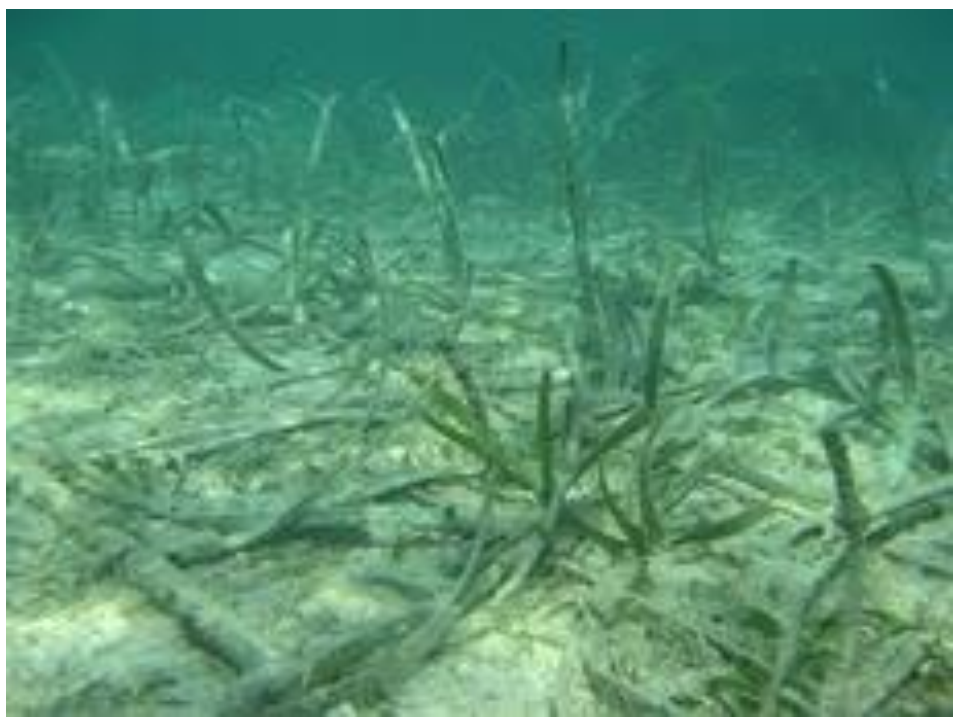

Mengingat dengan menggunakan balok dan kawat akan meningkatkan biaya, maka disarankan menggunakan plastik bentuk kasa (net). Beberapa tanaman dapat tumbuh dengan cepat dengan menggunakan teknik ini.

Penanaman metode spring tanpa jangkar telah banyak berhasil. Metode ini ditanam dengan cara menggali sebuah lubang kecil pada substrat (dalamnya kira-kira $8 \mathrm{~cm}$ ), kemudian ditutup dengan substrat yang sama. Metode ini hanya bisa berhasil jika arus atau gelombang yang rendah.

\section{Metode plug}

Yaitu pengambilan bibit tanaman dengan patok paralon dan tanaman dipindahkan dengan substratnya. Biasanya menggunakan paralon (PVC) dengan diameter $10 \mathrm{~cm}$ untuk jenis Holodule, sedangkan Zosteria, Thallasia dan Syringodium berdiameter $15-20 \mathrm{~cm}$. metode plug dengan menekan ke tanaman masuk ke substratnya, kemudian ditransplantasi pada lobang yang sama pada kedalaman $15-20 \mathrm{~cm}$. 
Phillips et al. (1978) merekomendasikan bahwa metode plug untuk Zostera ditransplantasi pada kedalaman $45 \mathrm{~cm}$ atau lebih. Sebagaimana pada percobaan di pelabuhan St. Joe, Florida menunjukkan bahwa dengan jarak tanam $15 \mathrm{~cm}$ muncul rumpun yang padat, akan tetapi pada jarak $30 \mathrm{~cm}$ tidak ada tumbuhan yang padat.

Untuk menghindari kerusakan yang permanen dari padang lamun donor, maka pengambilan tanaman dengan plug jangan terlalu dekat dengan yang lain. Jarak satu sama lain bervariasi antara 0,5 sampai 1,0 m (Phillips, 1978)

Metode 1 merupakan metode penanaman (planting), sedangkan metode 2 dan 3 adalah metode transpalnasi (transplantation).

Tabel 1. Waktu penanaman menurut jenis dan lokasi (PHILLIPS 1980, AZKAB 1987, 1988)

\begin{tabular}{|c|c|c|}
\hline $\mathrm{Jen}$ is & Lokas i & W a k t u \\
\hline Zostera marina & $\begin{array}{l}\text { pantai Alaska dan Alantaik utara, } \\
\text { Carolina Utara }\end{array}$ & $\begin{array}{l}\text { Maret atau Mei sampai } \\
\text { akhir Juli }\end{array}$ \\
\hline v & $\begin{array}{l}\text { Beufort, Carolina Utara, } \\
\text { bagian sclatan pantai Atlantik }\end{array}$ & $\begin{array}{l}\text { akhir September sampai } \\
\text { awal Desember }\end{array}$ \\
\hline & $\begin{array}{l}\text { Washington sampai selatan } \\
\text { Calofornia, pantai Pasifik }\end{array}$ & $\begin{array}{l}\text { Januari sama Mei (tetapi } \\
\text { dapat sepanjang tahun }\end{array}$ \\
\hline Halodule wrightii & $\begin{array}{l}\text { pantai Teluk, pantai Atlantik, } \\
\text { selatan tanjung Canaveral, } \\
\text { Florida }\end{array}$ & $\begin{array}{l}\text { setiap saat sepanjang } \\
\text { tahun }\end{array}$ \\
\hline $\begin{array}{l}\text { Thalassia testudinum, } \\
\text { Syringodium filiforme }\end{array}$ & $\begin{array}{l}\text { pantai Teluk, pantai Atlantik, } \\
\text { selatan Tanjung Canaveral, } \\
\text { Florida }\end{array}$ & $\begin{array}{l}\text { plug: Desember-April, } \\
\text { seeding, untuk Thalasia : } \\
\text { Agustus - November, yang } \\
\text { diproduksi di lapangan }\end{array}$ \\
\hline $\begin{array}{l}\text { Cymodocea rotundata, } \\
\text { Thalassia hemprichii }\end{array}$ & $\begin{array}{l}\text { ratatan terumbu Pulau Pari } \\
\text { Kepulauan Seribu, Indonesia }\end{array}$ & setiap saat sepanjang tahun \\
\hline
\end{tabular}


Tabel 2. Persentase tumbuh dari masing-masing jenis dengan metode yang berbeda

\begin{tabular}{|c|c|c|c|}
\hline Jenis & Lokas i & Metode & Persentase (\%) \\
\hline Thalassia testudinum & $\begin{array}{l}\text { Biscayne Bay } \\
\text { North Biscayne Bay } \\
\text { Turkey Point }\end{array}$ & $\begin{array}{l}\text { Sprig } \\
\text { Seed } \\
\text { Seed }\end{array}$ & $\begin{array}{l}90(1) \\
84(2) \\
80(2)\end{array}$ \\
\hline Halodule wrightii & $\begin{array}{l}\text { Nort Biscayne Bay } \\
\text { Jamaika } \\
\text { Lake Surprise }\end{array}$ & $\begin{array}{l}\text { Sprig } \\
\text { Plug } \\
\text { Sprig }\end{array}$ & $\begin{array}{r}54(2) \\
63(2) \\
100(2)\end{array}$ \\
\hline Zostera marina & Whidbey Island & Anchor & $40(3)$ \\
\hline Cymorocea rotundata & Pulau Pari & $\begin{array}{l}\text { Plug } \\
\text { Sprig }\end{array}$ & $\begin{array}{l}38(4) \\
43(4)\end{array}$ \\
\hline Thalassia hemprichii & Pulau Pari & $\begin{array}{l}\text { Plug } \\
\text { Sprig }\end{array}$ & $\begin{array}{l}78(5) \\
73(5)\end{array}$ \\
\hline
\end{tabular}

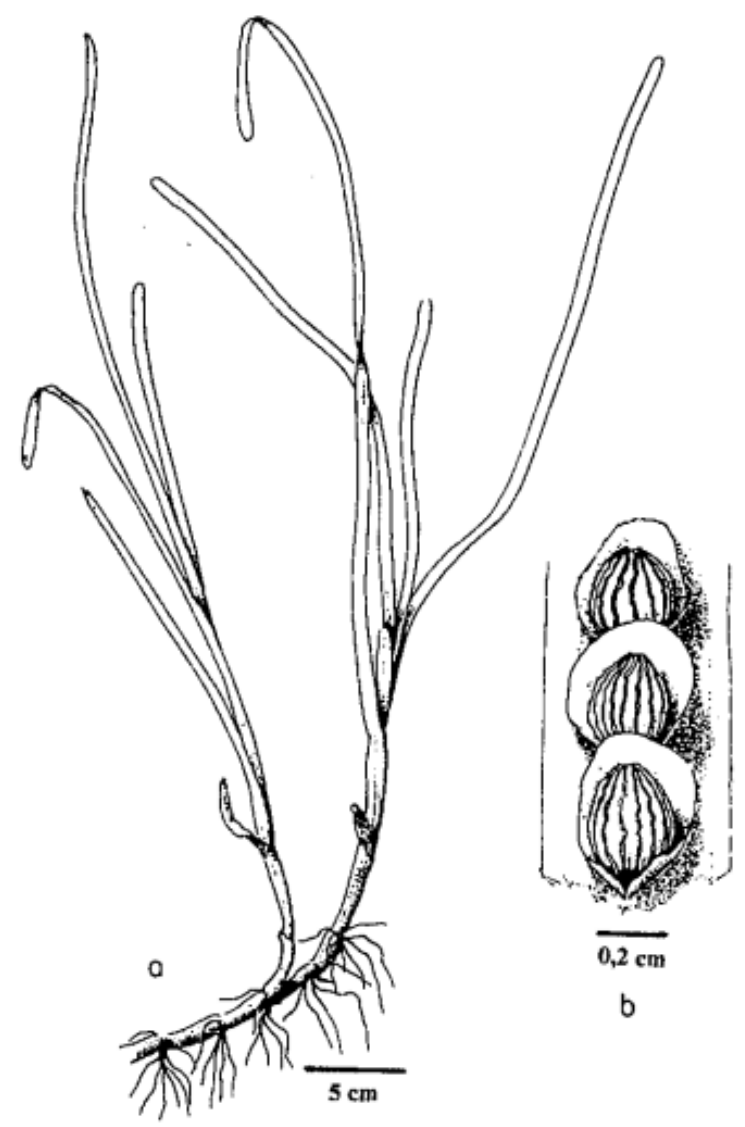

Gambar : a. bentuk vegetatif Zostera matina 
b. biji yang sudah tua.

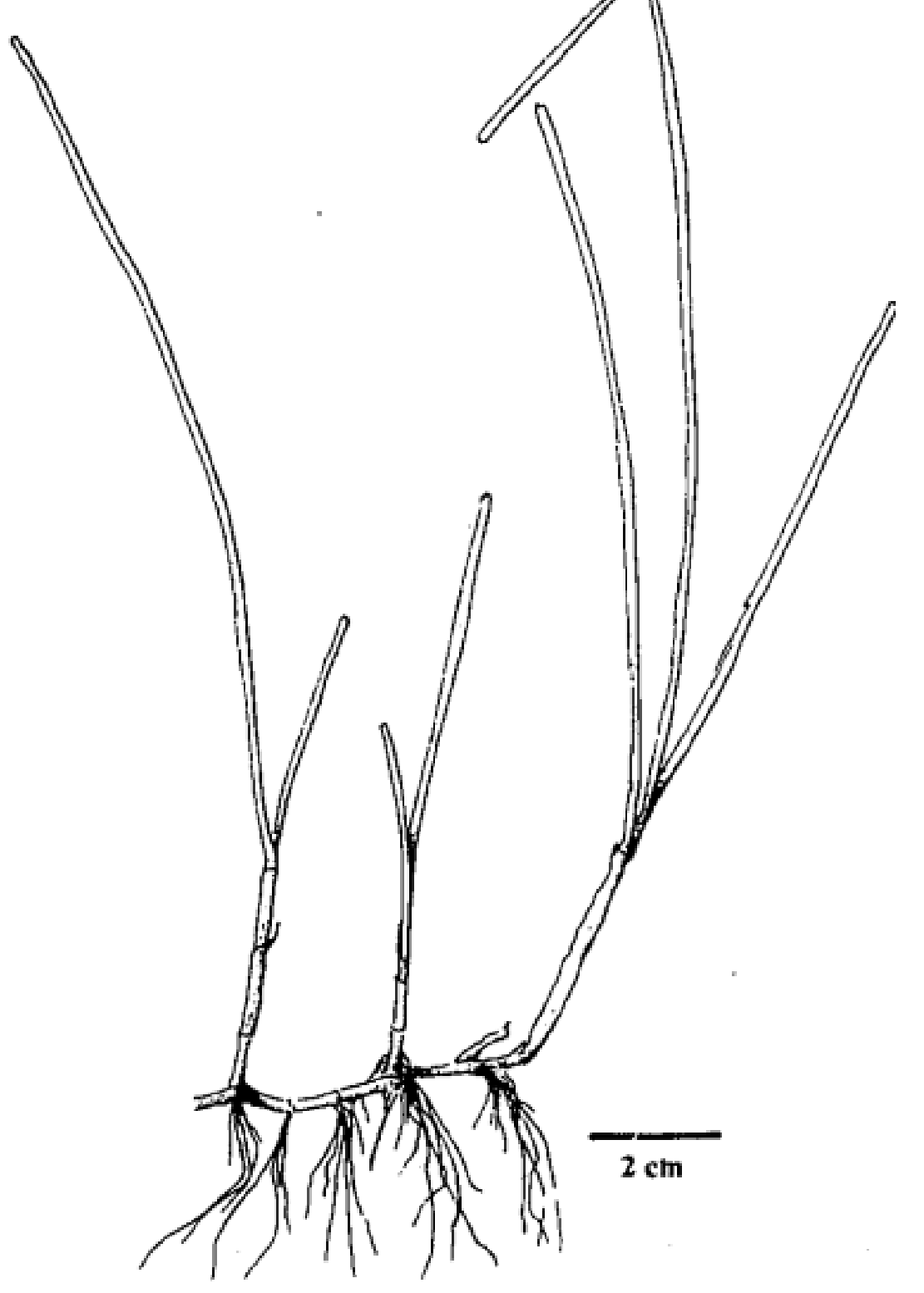

Gambar. Bentuk vegetatif Holodule wrightii 


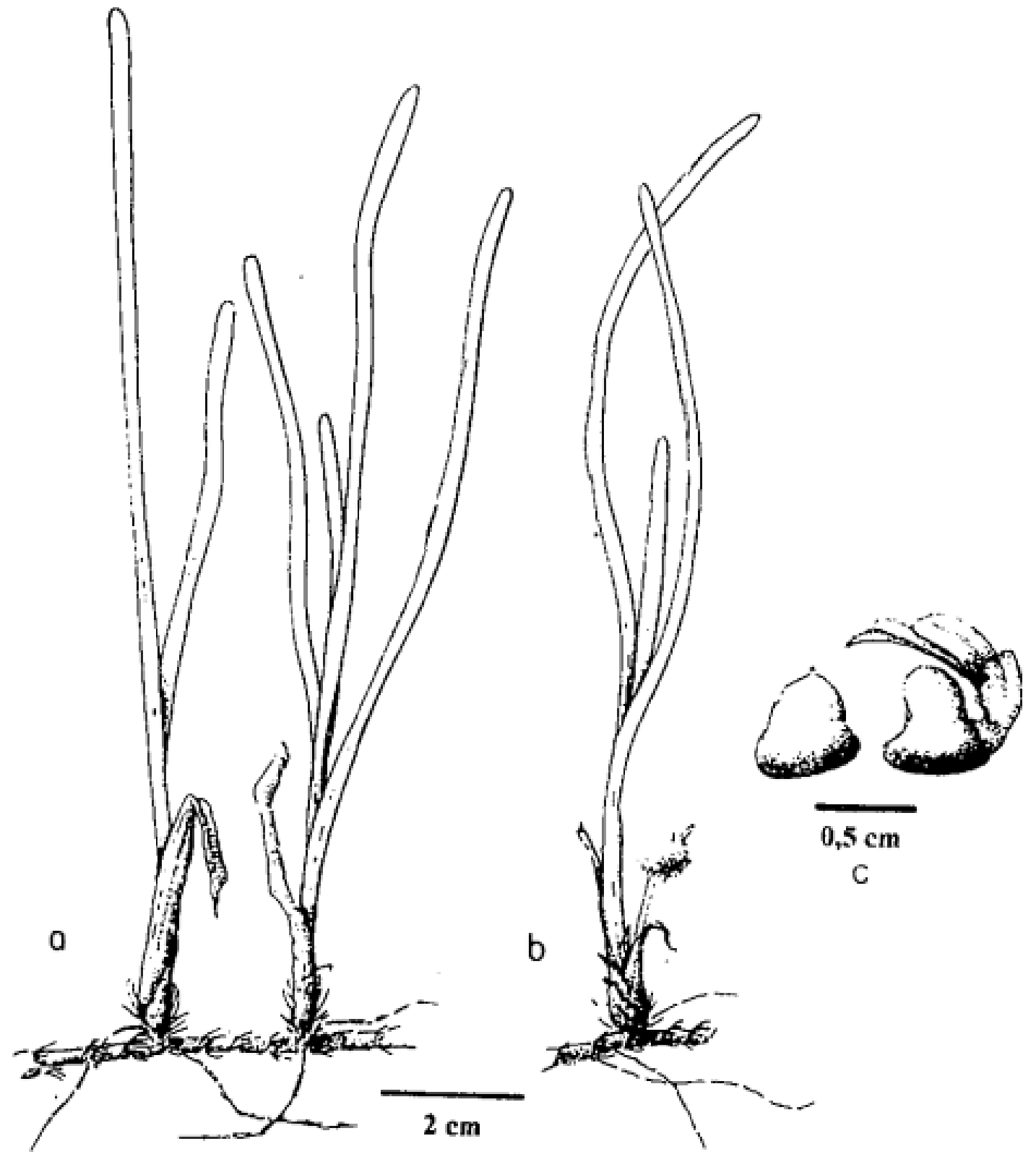

Gambar : a. bentuk vegetatif Thallasia testudinum

b. bentuk reproduktif dengan buah yang tua

c. biji yang sudah berkecambah

(Sumber : Husni Azkab, 1999) 


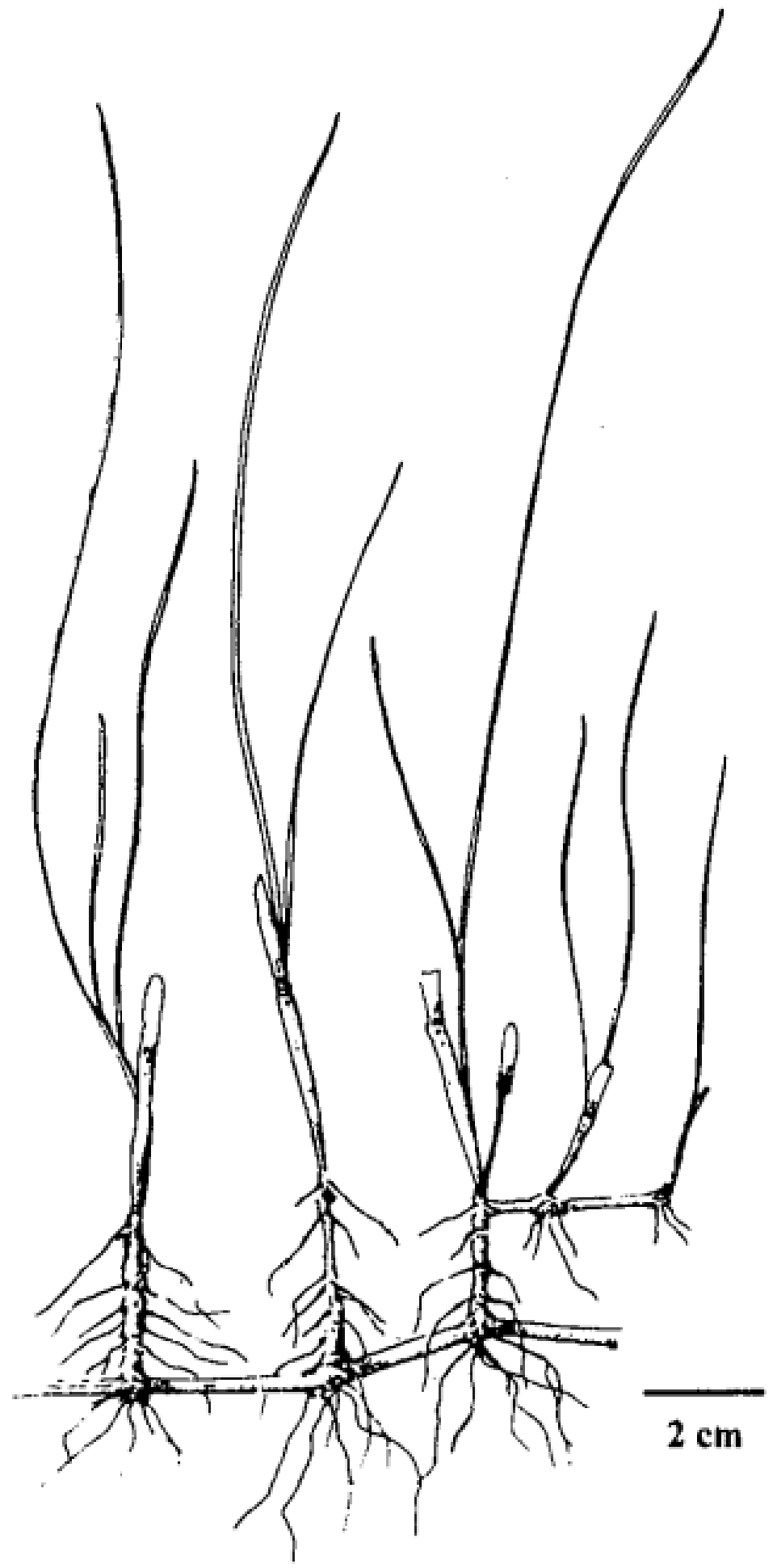

Gambar : bentuk vegetatif Spyringodium filiforme

N 


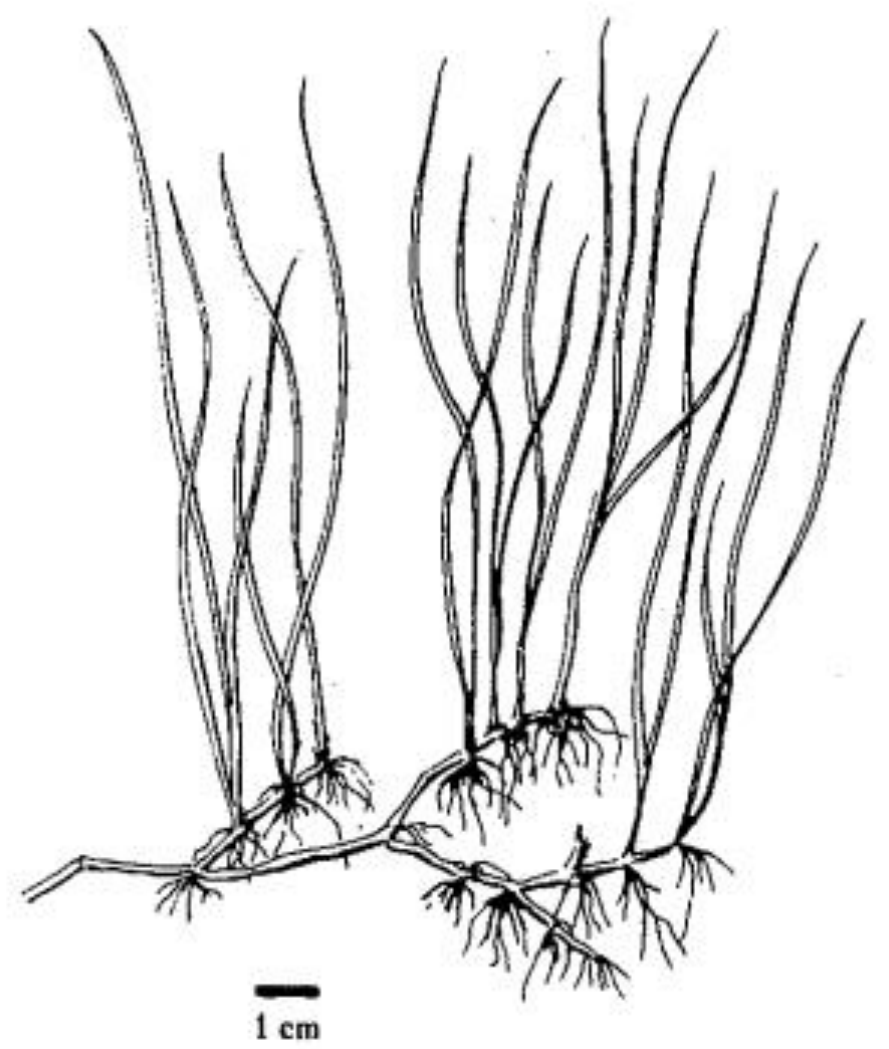

Gambar : bentuk Vegetatif Ruppia maritima

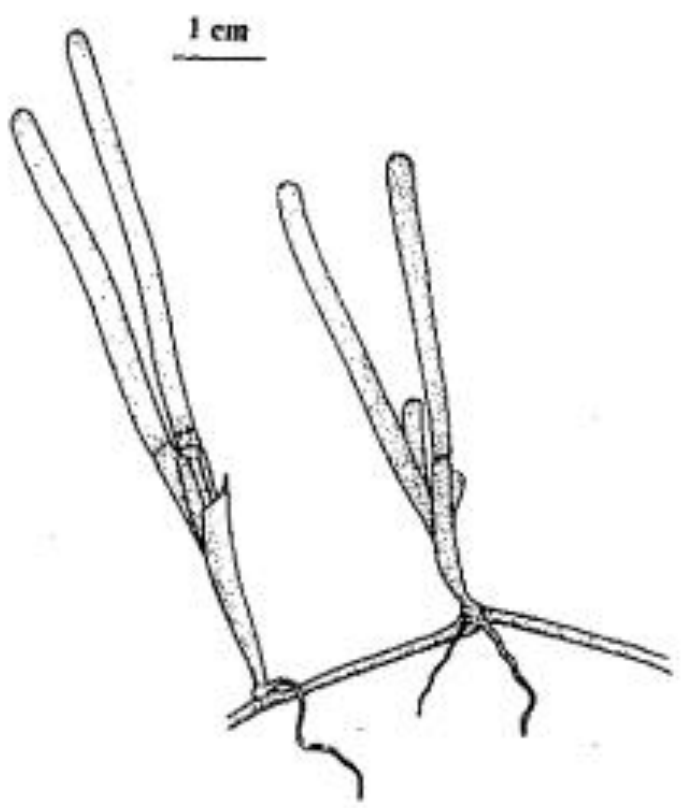

Gambar : bentuk vegetatif Cymodocea rotundata 


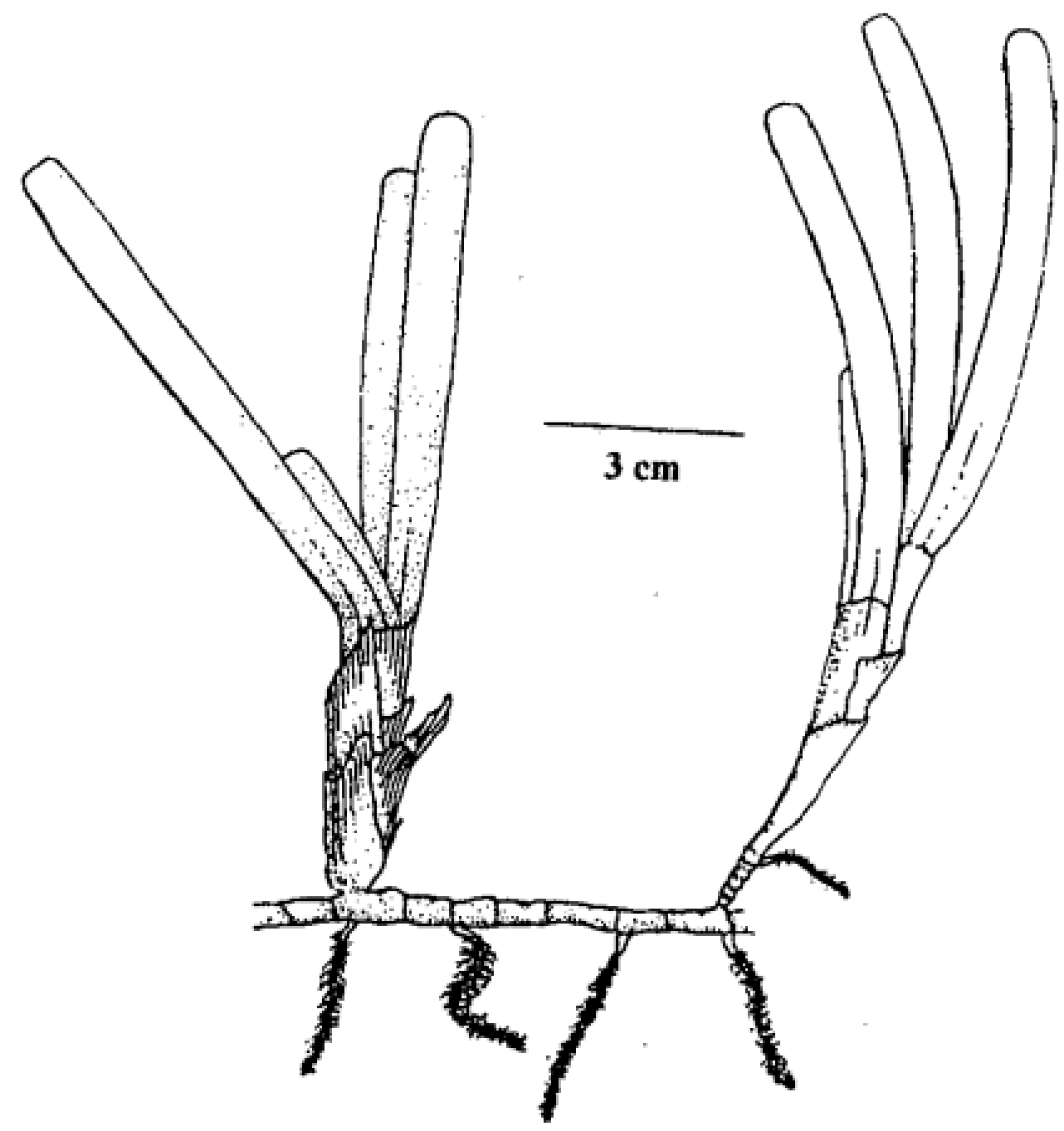

Gambar. Bentuk vegetatif Thallasia hemprichii

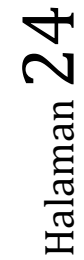




\section{DAFTAR ACUAN}

Azkab, MH. 1999. Petunjuk Penanaman Lamun. Jurnal Oseana, Volume XXIV, Nomor 3, 11-25. ISSN 0216 - 1877.

Bengen, D.G. 2002. Ekosistem dan Sumberdaya Alam Pesisir dan Laut serta Prinsip Pengelolaannya. PK-SPL. IPB, Bogor.

Bengen, D.G. dan A. Rizal. 2002. Perspektif Ekonomi Politik dalam Pemanfaatan Sumberdaya Pesisir dan Laut Indonesia. Bunga Rampai Pemikiran. Pusat Pembelajaran dan Pengembangan Pesisir dan Laut, Bogor. Hal. 3-6.

Bengen, D.G. 2003. Struktur dan Dinamika Ekosistem Pesisir dan Laut (Power Point). Disajikan pada perkuliahan: Analisis Ekosistem Wilayah Pesisir dan Lautan. Prog. Studi SPL. IPB, Bogor. (program komputer).

Dahuri, R., J. Rais, S.P. Ginting dan M.J. Sitepu. 2001. Pengelolaan Sumber Daya Wilayah Pesisir dan Lautan secara Terpadu. Pradnya Paramita, Jakarta.

Dahuri, R. 2002. Paradigma Baru Pembangunan Indonesia Berbasis Kelautan. Orasi Ilmiah: Guru Besar Tetap Bidang Pengelolaan Sumber Daya Pesisir dan Lautan Fakultas Perikanan Dan Ilmu Kelautan. IPB, Bogor.

Dahuri, R. 2003. Keanekaragaman Hayati Laut - Aset Pembangunan Berkelanjutan Indonesia. PT. Gramedia Pustaka Utama, Jakarta.

Hutomo, M. and S. Martosewojo. 1977. The Fishes of Seagrass Community on The West of Burung Island (Pari Islands, Seribu Islands and Their Variation in Abundance). Marine Research in Indonesia. 17: 147-172.

Keogh, M.J. and G.P. Jenkins ...... Seagrass Meadows and Their Inhabitans. Department of Zoology. University of Melbourne. Parkville, Victoria 3052.

Nontji, A. 1987. Laut Nusantara. Penerbit Djambatan, Jakarta.

Phillips, R.C, MK. Vincent dan RT. Hoffman, 1978. Habitat development field investigations. Port St. Joe Seagrass Demontration Site. Technical Report D78-33. Army Engineer Waterways Exp. St. Vicksburg, Missisipi, 37p.

Trono, G.C. jr and E.T. Ganzon - Fortes. 1988. Philippine Seaweeds. Marine Science Institut University of The Philippinines, Diliman Quezon City. Philipines. 